CIRR XXIII (79) 2017, 157-188

ISSN 1848-5782

UDC $321.7(620)$

DOI 10.1515/cirr-2017-0018

\title{
The Quo Vadis of Democratization in Post-Egypt Arab Spring
}

Gonda Yumitro, Heavy Nala Estriani

\section{Abstract}

This paper aims at examining how democratization in post-uprising Egypt remains flawed and the reasons for this failure. As a background, democratization in post-Arab Spring Egypt has collapsed and it seems now merely an illusion. The situation worsened since Egypt's democratically elected President Morsi was expelled from office through a coup, following mass protests demanding Morsi's discharge. Egypt's democratization is hard to achieve due to the shadow of the Pharaoh in Egypt, that is, entrenched ruling elites; Egypt's democratization process can never succeed while Egypt's old ruling elites are reluctant to allow this to happen.

KEY WORDS:

democracy, transition, Egypt, Arab Spring 
The period after the 2011 Arab Spring toppling of Hosni Mubarak brought high expectations among Egyptians to rebuild Egypt as a democratic country. Although expectations were quite high, the military coup led by Abdul Fatah El-Sisi on 3 July 2013 towards Egypt's first democraticallyelected president, Mohammad Morsi, retarded the process of democratic transition in Egypt.

Since then, despite seizing power, the military has installed an interim government led by Adly Mansour, the former head of the Egyptian supreme constitutional court. The military-backed interim government guided the country along the roadmap drafted by the military. In the meantime, the victory of Abdul Fatah El-Sisi in Egypt's 2014 presidential election, which was backed by the military, failed to lead the nation through democratic transition. Under Sisi, Egyptian authorities decided to criminalize the Moslem Brotherhood, the oldest and most influential Islamist group in Egypt. In 2014, the courts decided to dissolve the Moslem Brotherhood's political wing, the Freedom and Justice Party (FJP) - to which Morsi belongs - and the party was also excluded from Egypt's 2015 parliamentary elections in order to prevent the rise of "extremists" (Aly and Essaila 2016).

Afterwards, conditions worsened when the mass media became controlled by the government. Moreover, a great number of civilians were in detention, undergoing military trials, following the banning of civil society and pro-democracy organizations by the authorities, and the passing of several laws restricting the rights of Egyptians.

This paper contains six sections. In the first section the paper provides an overview of Egypt's democratization process prior to the 2011 Arab Spring in Egypt. In the second part, the paper discusses the turmoil of Egypt's 25 January revolution that led to the fall of Mubarak's regime. It also examines the flawed democratic transition in the hands of the military under SCAF and the environment in which Morsi was elected as Egypt's first democratically elected president. 
While the third section examines Morsi's administration's policies when he was in power, and his missteps in building relations with the military and opposition, the fourth part observes the role of Egypt's military in Morsi's discharge, the election of president Abdul Fatah El-Sisi, and the military's dominance over Egyptian politics and economics that is hindering the prospect of democratization in the country.

The exclusion of Islamic groups and the restriction of civil society and Non-Governmental Organizations (NGOs) during President Sisi's period are described and explained in the fifth section of this paper. The last and sixth section provides a deep analysis of the research question and a theoretical framework for understanding the problems raised.

This paper aims at presenting a brief description and analysis to explain the failing process of democratization in post-Arab Spring Egypt. It also presents a brief overview of recent events and the development of Egypt's democratization during the leadership of the current president, Sisi. The main purpose of this paper is to find the cause of democratic degeneration in post-2011 Egypt, which has resulted in the Arab Spring to appear as an illusion. This study applies a qualitative comparative approach method to address the problem of the study. As will be explained later in the paper, a comparative approach was used to deepen and strengthen the hypothesis of this study, which was done through analysing the failed transition of recent events. Ultimately, the theories and concepts of democratization, democratic transition, and civil society are the most suitable concepts to be applied in this paper.

\section{Literature review}

In the meantime, due to an unachievable consensus over a definition of democracy among scholars, there are a lot of interpretations of democracy, resulting in different kinds, types, and conceptualization on what democracy actually is. 
Larry Diamond's Developing Democracy toward Consolidation gave a definition of electoral democracy, which previously was posed by Joseph Schumpter as a minimalist democracy. This is to say that a country is claimed to be a democratic one when it is at least able to address certain requirements such as a multi-party system and regular elections to assume government office. This minimalist democracy, also known as procedural democracy, is considered to be suitable for a country that has just entered the democratic transition stage (Diamond 1999: 9-10).

However, Alfred Stepan and Juan Linz argued that democracy cannot be merely viewed from the elements of procedural democracy such as elections and a multi-party system. Democracy should have a constitution to guarantee the basic freedoms, rights, and protections towards the rights of minority groups. Essentially, democracy has to be interpreted substantially. This means that democracy should be applied in everyday life and be part of the political culture that can guarantee the basic rights and ensure the freedoms of individuals and groups (Stepan 2000: 39).

Regarding this substantial democracy, the Egyptian Constitutions of 1971, 2012 and 2014 have illustrated Egypt as a democratic state. The constitutions clearly describe the substantial democracy that addresses the basic rights and freedoms of any individual. Equal opportunity, freedom of thought, participation of women, freedom of the press, protection from violence, etc. are some of rights and freedoms guaranteed by the Egyptian constitutions. It means that these constitutions have guaranteed human rights values and supported Islamic Shari'a in a liberal perspective (Lombardi and Brown 2005). Although liberalization processes in Egypt can be traced from the era of Anwar Sadat through various elections, a multiparty system, and economic development, the fulfillment of basic rights and freedoms has constantly been violated. The infringement of these rights and freedoms have become more intense during the turmoil since Mubarak's resignation, the events of Morsi's downfall, and Abdul Fatah El-Sisi's coming to power.

Jeffrey Haynes argues that the development of a democratization process cannot be separated from these four stages: (1) political liberalization; (2) the collapse of the non-democratic regime; (3) democratic transition and; (4) democratic consolidation (Haynes 2013: 2). In that process, after 
the collapse of the authoritarian regime, the country has entered the stage of a transition process. The study of democratic transition has been increasingly widespread and developed especially during the third wave of democratization from 1974 until the 1990s when more than thirty nondemocratic countries turned to democracy (Huntington 1991: 12).

In the case of Egypt, the downfall of Mubarak's non-democratic regime put the country into a transitional period, particularly when the head of the Supreme Council of the Armed Forces (SCAF), Field Marshal Muhammad Hussein Tantawi, led the transitional process until the next presidential election was held (Stein 2012: 5). Grasping the meaning of transition introduced by O'Donnel and Schmitter, in which they define transition as the interval between the fall of an authoritarian regime and the establishment of a new regime (whether democratic, authoritarian, revolutionary or hybrid) (O'Donnel et al. 1986: 6), the transitional period in Egypt ended when SCAF handed over power to Morsi, Egypt's first democratically-elected president.

However, the transition process is deemed to be quite a difficult and long process, as one of the outcomes is conflict among political parties and interest groups (O'Donell 1994: 60). This happens because the transition process is marked by an increase of public participation, political liberalization, enhancement of civil rights, as well as the implementation of democratic procedures in public spheres. Yet, each country has its different implementation of the transition process in accordance with the conditions prevailing in that country. Hence, noting the events in the post-Morsi era, Egypt is still completely in the process of the so-called democratic transition.

Stephen J. King's The New Authoritarian in the Middle East and North Africa emphasizes that authoritarianism in the Middle East and North Africa (MENA) is both persistent and dynamic (King 2009: 5). He argues that most countries in the region began to proceed into democracy in the 1980s and 1990s. However, the region did not directly turn into a democratic one. Rather, he argues that the system invented a new model of authoritarianism, replacing its predecessor, 'old authoritarianism' (King 2009: 31-32). 
Samuel Huntington's Democracy's Third Wave pointed out that the emergence of liberalization in some of the Middle East and African countries in the 1990s was the impact of the 'snowballing' of democratization taking place in other countries such as in Eastern Europe (Huntington 1991: 16).

Michael Schulz's The Role of Civil Society in Regional Governance in the Middle East, in the volume Civil Society and International Governance edited by David Amstrong and Valeria Bello, aims to highlight the development and the furtherance of civil society in the Middle East. He explains that the emergence of civil society in the Middle East in the 1990s was supposed to be the forerunner for the development of democracy in the region. However, the enhancement of civil society in the region is not as vivid as in many other regions in the world, as it is often controlled and movements are restricted by the state apparatus (Muhkabarat) (Schulz 2011: 166-171).

Amy Hawtorn's Middle Eastern Democracy: Is Civil Society the Answer stresses that in many Arab countries, the growing number of civil society organizations do not lead the country to democratization. State repression has become the main challenge, limiting the space and activities of civil society. The durable authoritarianism in the region has weakened the role of civil society (Hawthorne 2004: 10). Meanwhile, the role of civil society is significant to the country as it reinforces democracy through public scrutiny (Nanz and Steffek 2004: 324).

Many believe that the upheaval that surged in most Middle Eastern countries in late 2010 was the path for the region to be able to open up to democratization. In his book Beyond the Arab Spring: The Evolving Ruling Bargain in the Middle East, Mehran Kamrava offers an analysis that durable authoritarianism in the Middle East was maintained by the ruling bargain in which the government guarantees the prosperity of the people. Instead, the ruling autocrats could only maintain their durable authoritarianism by banning political parties and taking control of civil society, NGOs, and trade unions (Kamrava 2014: 20).

Kamrava then mentions the rise and fall of the ruling bargain which also became the cause of the emergence of the Arab Uprisings in 2011 . He points out two advancements behind the upheavals in the region. The 
first significant factor is the ease in getting information on other events in the region, which relates to the enhancement of education and the rapid emergence of both traditional and new media in the region. Second, the states that were affected by the unfolding crisis had a dynamic response (Kamrava 2014: 39).

Departing from this point, it is clear that the new media (social media) has had a great impact in advancing information to the region. Facebook and Twitter are the tools which made a contagion effect, starting from the Tunisian revolution, to Egypt, Libya, Yemen, Syria, Bahrain, and eventually becoming more dynamic. Hand in hand with Kamrava, Lachen Achy (Achy 2012) argues that the inability of these Middle Eastern rulers to maintain their authoritarian bargain is affected by several factors, namely economy, demography, and education.

In Egypt, though Mubarak's overthrow has moved the country into a democratic transitional stage, the transition and democratic process in Egypt remain uncertain. Even after the victory of Morsi in Egypt's first democratic elections in 2013, the insurgency in Egyptian political, social, and economic spheres were undeniable. No matter how much the Egyptian democratic movements insisted on turning the country into a democratic one, the authoritarians' tone still remains strong in Egypt's democratization process.

One of the factors hindering the democratization process is the military. The roles of Egypt's military in dominating the everyday life of Egypt's people have been beyond doubt for decades. Amos Perlmutter, in Egypt, The Praetorian State, argues that Egypt is a praetorian state where the potential for the state to be dominated by the military remains high. He argues that in countries where civil governments fail to legitimate themselves, the military appears and intervenes in civilian affairs and often dominates them (Perlmutter 1974: 4-5). He still argues that mostly, praetorian elements exist in developing and underdeveloped countries, where the executive body is ineffective and compounded by political decay. In addition, when the authoritarian regime falls, the army tends to intervene in the transition process as the political sphere is stuck in a fragile condition (Perlmutter 1977: 18). 
Hand in hand with Perlmutter, Samuel Huntington, in Political Order and Changing Societies, argues that military involvement is not only based on military affairs but also for political purposes. Thus, these socalled praetorian measures are not only undertaken by the military but also by social forces that are highly politicized and influenced by the military. This is what Huntington calls a praetorian society; further, such mobilization along the interests of the military would worsen already weak government institutions and their ability to articulate public interest (Huntington 2006: 195-196).

In the case of Egypt, although the military dominates Egypt's structural, institutional and even constitutional spheres, but we cannot say that Egypt is totally ruled by the military, like the military Junta in Myanmar. Unfortunately, still, the military's ascendancy goes hand-in-hand with the prolonged existence of authoritarianism in Egypt, along with the ruling elites, the so-called "deep state", which indeed cannot be seen except in an abstract way. These types of military roles have maintained the endurance of the authoritarian regime and hindered the process of democratization in Egypt.

As Georg Sørensen points out, the success of a democratic transition process cannot be separated from the interference of elite groups (military, economic, and political elites) in order to protect their interests. In most cases, these countries have democratic elements but transition is limited in its completion. Public participation and freedom, which are the foundations of building political democracy, are limited. This kind of democracy is called by Sørensen a restricted democracy (Sørensen 2008: 46-49). This kind of democracy was used by the Mubarak regime to maintain its power over 34 years, an authoritarianism hidden behind democratic ideas.

These kinds of concepts are used in explaining the developments, and reversals, of Egypt's democratic process. 


\section{Egypt's democratic experience}

Egypt's democratic experience started once the country gained independence from British occupation in 1922. It can be seen through the implementation of the 1923 constitution in which a parliamentary democratic system was established, allowing civilians to have greater liberty (Dunne and Hamzawy 2008: 18). However, liberalization could not help Egypt escape from economic and social problems, since the influences of British colonialism remained for the next thirty years. This situation eventually led to a coup conducted by the Free Officer Movement against the monarchy regime in 1952. Since then, Egypt has been led by autocrats with a military background (Hassan 2010: 320).

In Gamal Abdul Nasser's years in power, the development of democratization was challenged by some of Nasser's policies, restricting the development of basic democratic elements. Nasser then abolished political pluralism that had been developed in the previous monarchic era, by imposing a one-party political system with the dissolution of parliament and banning the existence of opposition groups, both Islamist and leftist. Indirectly, the policy had given Nasser all executive power and made him Egypt's greatest power holder (Selim 2015: 30-31).

This condition is compatible with the idea of Mehran Kamrava's assertion of the use of an authoritarian bargain by Nasser, in his populist days between 1950s-1960s, in order to forward his political interests. In such a condition, his power was strengthened and coloured by these political patterns (Kamrava 2014: 20).

Following Nasser's death, his successor, Anwar Sadat, marked a turning point, transforming Egypt's political, economic, and foreign policies towards political and economic liberalization that was opposite to Nasser's socialism (Hassan 2010: 321). One of Sadat's liberalization policies, The Infitah (open-door) was introduced in order to enhance foreign investment. Thus, economic liberalization is closely related to the shift of Egypt's foreign policy from Russia under Nasser, to the west, which in this case is America, under Sadat (Baker 1981: 378). The decision to 
turn from the east to the west forced Egypt to re-consider its openness to democratization, since America embraced the democratic agenda. In this way, as a form of acceptance to the American side, economic and political liberalization became priority matters in Sadat's years in power.

In order to enhance political liberalization, Sadat attempted to introduce a multiparty system. It was marked by the publication of Law 40/1977, in which five political parties were established. The Social Liberalist Party stood for the right, the National Progressive Party represented the left, the Socialist Labor Party, New Wafd Party and the centrist Egypt Arab Socialist Party, which afterwards Sadat changed to the National Democratic Party (NDP) were directed by Sadat himself (Selim 2015: 32). However, Sadat's rule was not so different from his predecessor Nasser, as he decided to diminish the role of the opposition, individual parties and the media by releasing a number of decrees of restriction and repression (Selim 2015: 33).

The reasons for this political shift were that, at the outset of his power, Sadat needed the political legitimacy and support from the Egyptian people, in coping with any domestic issues regarding political instability (Barnett and Levy 1991: 379). He would change his image from an authoritarian, to democratic leader, although he realized that it was not easy. In fact, he indeed had to tackle serious problems regarding Egypt's economic condition and security, leading him back to behaving similarly to Nasser as an authoritarian leader.

Despite the liberalizations receiving a positive reception, mainly from the west, the consequences to Egyptian's domestic conditions were quite severe. The reduction of subsidies on basic commodities resulted in the appearance of massive demonstrations and riots in Egyptian cities in early 1977. Thus, government policies to reduce subsidies were to show financial responsibility to major aid agencies and foreign investors from wealthy donor countries like the USA, Saudi Arabia and Kuwait. The mass protests resulted in casualties, with 79 people killed, 1000 wounded and 1250 jailed (Baker 1981: 381).

Anwar Sadat's successor, Hosni Mubarak, implemented policies aimed to restore stability. Mubarak released political prisoners and called for national reconciliation among political opponents. He then increased 
press freedoms and allowed the establishment of political parties, which led to the presence of 24 political parties during Mubarak's ruling years (Selim 2015: 34).

However, although there were several elements of electoral democracy found in his leadership, through legislative and presidential elections, Mubarak's fifth victory in Egypt's presidential elections cannot be separated from suppression towards opposition groups, judges, journalists, and the Moslem Brotherhood, who all challenged the continuity of his power (Arafat 2011: 20-151). In his book, Arafat mentioned some factors hindering democratic transition during Mubarak's rule, such as weak opposition parties and civil society, the difficulty of concluding a peaceful transition, rampant corruption, de-liberalization policies, and the threat of retribution (Arafat 2011: 137-153).

The depiction of Mubarak's electoral democracy was the picture of authoritarianism in the age of democratization. In a sense, in the midst of the demands of the people as well as huge international pressure for the country to move closer towards democracy, the authoritarian regime in Egypt used the electoral system as a shield, branding the country as one in the consolidation process of democratization, even though the reality was quite different (Brownlee 2007: 2)

The aforementioned policies were depicted by Larry Diamond as pseudo democracy, in which the existence of a non-democratic regime is covered by formal democratic elements such as elections and a multiparty system (Diamond 1999: 17). In the case of Egypt, the ruling party, NDP, maintained its hegemony in most of Egypt's parliamentary elections. Thus, the tactics of the NDP and Mubarak cannot be separated from repression, patronage, and media control by the Mubarak regime.

\section{Post-Egypt uprising: flawed transition}

The wave of democratization, also known as Arab Spring, surged through 
the Arab world in the last quarter of 2010, leading to mass protests demanding the downfall of various authoritarian regimes in the region. Egypt was no exception, experiencing severe protests after being controlled by Hosni Mubarak for 30 years (Nassif 2013).

The major reason why this large-scale mass-protest took to the streets demanding the autocrat's downfall, is due to the rupture of the ruling bargain between the regime and the people. In recent decades, the durable autocrats in the Arab world proffer social services to the people in lieu of minimizing the role of citizens in the decision making-process (Yahya 2017: 3)

In Egypt, the protests demanding the ouster of Hosni Mubarak showed the fury of the people as Mubarak failed to preserve the ruling bargain he had maintained for decades. The flawed authoritarian bargain in Arab States, and particularly in Egypt, was due to the inability of these autocratic regimes to cope with demographic growth, a youth bulge, and unemployment over the past decades. The situation was also worsened by the ruler's combining of repression, economic benefits, and political concessions (Achy 2012).

The key elements of the revolution, such as youth, social media, activism, civil society, and NGOs, were consolidating their power to ouster the last 'Pharaoh of Egypt'. It can be assumed that the repression and the reluctance of the regime to embrace human rights and democracy had become the main reason for Egyptians to reveal their prolonged frustration, after 34 years of Mubarak's authoritarianism. In the midst of massive protests and the spontaneous military decision to side with the people, Mubarak then resigned from his office in February 2011. Mubarak's resignation had brought a huge expectation in the hearts of Egyptians to turn the country from authoritarianism to democracy (El-Sherif 2014: 3).

In the post-Mubarak period, the higher military council, Supreme Council of the Armed Forces (SCAF), held power during the transition period, after suspending the 1971 constitution and dissolving parliament. SCAF held a referendum and assured the freedom of the media and the youth, as well as paved the way for the legislative and presidential elections that took place afterwards (Kuncahyono 2013). 
For the first time, the people and the military seemed to be allied. The slogan "the army and the people are one hand" depicted the intimacy of these two allies. Moreover, in the months following Mubarak's ouster, the SCAF had promised to ensure the freedom of the media, youth and NGOs. However, in the following days, in the midst of political indeterminacy, as well as the postponement of a legislative election that was supposed to be held around six months after Mubarak's resignation, the people were frightened by ongoing military domination (McCormick 2011).

As a result, the rate of various mass protests and demonstrations significantly increased, and according to data from Amnesty International, SCAF took repressive measures against the media and civil society groups whose positions differed with SCAF's. In addition, various violations, including virginity tests held by the military towards women protesters in Tahrir Square, had insulted and harassed the rights of Egyptian women specifically (Mannheimer 2014: 18). Furthermore, the enactment of a state of emergency, as well as the military tribunals that tried civilians, which have existed since the Mubarak era, were considered to undermine the democratic expectations of the Egyptians. Ever since this period, the proximity of these two allies has been damaged.

From this flawed transition, the public wondered about the meaning of the January 25 revolution for the interests of the people. Indeed, the transition is producing a different level of achievement when compared to the Tunisian Uprising. The democratization process in Tunisia has been relatively more successful because of the smaller political role and intervention of the military.

In Tunisia, the military seems reluctant to be deeply involved in political affairs in the Tunisian transitional process. Zine El Abidine Bin Ali tried to dissociate the armed forces from political and economic affairs (Mannheimer 2014: 19). It was totally different in Egypt, where the military has played many roles in the transition and in fact dominated Egypt's economy ever since Nasser was in power.

In the case of Egypt, from the beginning of Mubarak's ouster, Egyptians have lost their opportunity to turn the country into a democratic one, due to the intervention of the military. However, it was not the people who 
chose the military to implement Egypt's transition. It was Mubarak who handed power to the SCAF, and the people had forgotten for a while that the military was part of Mubarak's legacy. At first, the people seemed glad and did not recognize SCAF's motives to maintain power. Moreover, the Egyptian military has had longstanding influence in protecting the country. But then, the broken promises by SCAF has made the people realize that they had ignored the worst things when the military comes to power - that it would be difficult for them to withdraw.

In the final quarter of 2011, which popularized the slogan "Down! Down with military rule", SCAF then held an election, both legislative and presidential. The Freedom and Justice Party (FJP), the party affiliated with the Ikhwanul Muslimin (Moslem Brotherhood) won the largest number of seats in both the upper and lower houses of parliament. In the presidential election that was held afterwards, Mohammad Morsi, the FJP candidate, claimed victory over Hosni Mubarak's Prime Minister, Ahmed Shafiq, and was declared Egypt's first democratically-elected president (Kuncahyono 2013: 204)

\section{Egypt under Morsi: losing an opportunity}

The victory of Morsi marked the first successful democratic transition in post-Arab Spring Egypt. Though he gained the presidency, Morsi still faced various economic, political and social problems left by the Mubarak regime. In the post-Mubarak era, Morsi was not only confronted by the demands of the people, but also had to deal with and build relations with Mubarak's remnants, called the deep state, that had been deeply rooted in Egypt's political, economy and social sphere.

While all parties anticipated the success of a democratic transition in Egypt, this has not emerged as easily as imagined. Since the very beginning, when Morsi came to power, the political polarization among Egyptian elites was noticeable and became one of the main challenges of Morsi's policy. Secular groups who felt betrayed by the military and the Moslem 
Brotherhood combined forces and formed an opposition group, the National Salvation Front (NSF), which later became Morsi's main political opposition in the country. The NSF boycotted Morsi's referendum on the draft constitution, held in late December 2012, arguing that the new constitutional draft was only benefiting Islamist party groups, dominated by the Moslem Brotherhood (Gerbaudo 2013).

Since then, the state has seen further divisions and polarizations which have ruined the democratic transition process. Consequently, those divisions have complicated Egypt's political decision making process. When one side of the party feels disadvantaged by a policy made by the other side, the deep rupture among the polarized parties cannot be avoided. The peak of public outrage happened during Morsi's 22 November constitutional decrees that granted him extensive powers, beyond the control of Egypt's courts. Those controversial decrees were considered by many in the opposition as the resurgence of a new Pharaoh (Gerbaudo 2013).

After Mubarak, the economic factors behind Mubarak's downfall caused greater devastation to the transitional process. These unresolved economic problems were worsened during Morsi's years in power. The high prices of basic foods, high rates of unemployment, and electricity and oil crises triggered more complaints and political instability. The percentage of the population living in poverty increased from $25.2 \%$ in $2010 / 2012$, to $26.3 \%$ in $2012 / 2013$, and the state debt increased from US $\$ 5$ billion/year up to $\$ 8$ billion/year a few days after the coup. Loans from the IMF and other sources of funds still cannot fix these problems (Farid 2014).

In Egypt, the Islamist party was unable to deal with political factions, in contrast with the Tunisian Ennahda Islamist party, which also won the first election in post-Ben Ali Tunisia. The very first time the Ennahda party was in charge, it managed to share power with various factions and created political partnerships with moderate secularist and moderate Islamist groups (Ghannouchi 2014).

Morsi failed to deal with the opposition, a failure compounded by his policies which tried to minimize the role of the military. The cases above have led to the emergence of anti-Morsi demonstrations, namely 
tamarrod which later led to the coup conducted by the Egyptian military (Mannheimer 2014: 17).

When the military decided to remove Morsi from power, Egypt lost the opportunity to build a democratic institution in the post-SCAF transition era. It seems difficult to describe what kind of democratic character Egypt has, if its first democratically-elected president was ousted not less than a year after he came to power.

\section{Egyptian democracy: dependent on the military}

The development of Egypt's democratization cannot be separated from the massive influence of the military since the fall of the monarchy in 1952. Since then, Egypt has been dominated by military autocrats and by a president who came from a military background until the downfall of Mubarak in 2011. In the Nasser era, Egypt was depicted as a military society. In such a political culture, the involvement of the military inside Egypt's political administration in the era of Nasser happened easily. Beyond that, Nasser also entangled the military in many countries with giant economic projects.

In the era of Sadat, despite the de-politicization of the military started by Sadat, the military still had many privileges and built the military-economic empire. It is estimated that around $40 \%$ of the total Egyptian economy came from business companies controlled by the military. It was also supported by $\$ 1.3$ billion in US military assistance annually since Sadat signed the Camp David accords in 1979 (Pappalarado 2011).

The position of the military grew stronger under Mubarak's regime. The military was granted many privileges, not only in the political, but also in the economic sphere (Sayigh 2012: 84). Since then, the military has built what Trias Kuncahyono expressed as "a state within a state", that has great impact on economic and social structures in Egypt (Kuncahyono 2013: 208). 
In the midst of deepened polarization and division with the mass protests demanding Morsi's resignation, military aircraft flew over the crowds and dropped the Egyptian flag, denoting that the military had decided to take the people's side. The anniversary of Mubarak's resignation on 30 June 2012 served as the culmination of protests towards Morsi's government. On the next day, General Abdul Fatah El-Sisi came on public television and announced a 48-hour ultimatum to Morsi, to take an immediate decision on Egypt's politics (Fisher 2013).

Morsi ignored El-Sisi's ultimatum, which forced the military to stage a coup against him and develop the roadmap for Egypt's future. After suspending the 2012 Egyptian constitution, the military then appointed Adly Mansour, the head of the Egyptian Supreme Court, to become an interim president, and formed a cabinet mostly consisting of Mubarak's remnants and retired military generals (El-Adawy 2013).

The military has enormous power in building Egypt's democratization process. It can be said that the success of Egypt's democratic transition is decided by the military. When Abdul Fatah El-Sisi gained a massive victory in the 2014 presidential election, the prospect of Egypt's democratization process was questioned. El-Sisi, who is backed by the military and its allies that were also behind the downfall of Morsi, increasingly indicated that the country was still under the shadow of the old ruling elites.

The shadow of the old regime has led to a flawed process of democratic transition in post-Arab Spring Egypt. It can be said that the repressive measures used by the SCAF, and the military coup towards Morsi, have depicted Egypt taking a hard-line approach to the country's ongoing transitional process. As noted by O'Donnell and Schmitter, the use of hard-line and soft-line approaches within the political elite have a large influence on the democratic transition process (O'Donnell et al. 1991). The soft-line approach makes it easy to facilitate, negotiate and compromise between split factions. In contrast, the use of a hard-line approach shows a country is reluctant to use diplomatic processes in implementing its transition process.

Alongside the use of a hard-line approach rather than a soft-line one, the military and the ruling elites or the old guards, still maintain their position 
in the hearts of the Egyptians. This is not only because the military has a long-standing history in protecting the country, but also due to the anti-Morsi protesters who had lost hope in an Islamist President's leadership. They also feared Ikhwanization that would Islamize the country in the same way as Iran after the 1979 Iranian revolutions. These were compounded with the support of the opposition groups and the United States, who has enjoyed long relations with the Egyptian military (Al-Amin 2013).

In accordance with the statement of Perlmutter as previously mentioned, the praetorian military appears and survives in a country where their institutions are weak and fragile or is still in the transitional process. Taking into account the fact that Egypt's military has deep connections in politics and the economy, and has tightened their relationships with the external actors, along with Egyptian ruling elites, it is clear that the success of transition and the democratic process is all in the hands of Egypt's military.

The question emerges: how could the military's role endure and maintain durable autocrats in Egypt, even after the country succeeded in toppling Mubarak and Morsi. Even the new President Sisi has insisted that the country has turned into a democratic one. In fact, ever since Egypt's first republic was formed, the ruling elites that mostly come from the military, are reluctant to turn the country into a democracy. As Egypt's major power holder, they would never let a civilian with no military background control them. Therefore, in the midst of international demands for a democratic system, they tend to let democracy arise by diminishing the role of dictatorial leaders and installing many characteristics of a democratic system. In fact, they construct scenarios to keep their power in place, much like how the military staged a coup of Morsi's government. Therefore, even when the dictatorial leaders have been overthrown, the military's power and interests are still in place, and governments with military backing remain. 


\section{The exclusion of islamists}

After the military staged a coup of Egypt's first democratically elected President, Morsi, there was strong resistance from Morsi's Islamist supporters, who assumed that military actions were not legitimate. Morsi's supporters undertook massive protests and demonstrations, demanding the restoration of Morsi's power as Egypt's president. Instead of receiving a positive response from Egyptian authorities, these groups suffered repression from security forces, both military and police.

The clashes between the security forces and Morsi's supporters heated up when Adly Mansour declared a state of emergency, which was applied during Mubarak's years in power. The declaration of a state of emergency was applied following the sit-in and mass protest of Morsi's supporters, demanding the restoration of Morsi (Bassiouni 2013: 1-4).

A thousand rallies held by Morsi supporters took place in two main locations, Raba'a Al-Adawiya and An-Nahda Square Cairo. The security forces moved directly to both locations without giving any notice or opportunity for protesters to leave the location peacefully. Those repressive actions were met with provocative actions by the demonstrators, making casualties inevitable. More than 300 people died and 1000 others were injured during the protest that occurred on 14 August 2013 (Bassiouni 2013: 4).

The media, with great influence in shaping public opinion on the recent events, has been polarized since Morsi came to power. Media such as Aljazeera Egypt, Misr25, Al-Hafiz, Ar-Rahma and An-Nas, which are considered to be sympathetic to the Moslem Brotherhood, were banned from broadcasting (Radsch 2013).

The intensity of societal polarization increased when Egypt's High Court announced the banning of the largest Islamic movement, the Moslem Brotherhood, and labelled the group as a terrorist organization. Brotherhood members and leaders were arrested and their assets were frozen. Moreover, their affiliated political party, the Freedom and Justice 
Party (FJP) was dissolved by the court and could not participate in legislative elections (El-Dine 2014: 3).

The decisions of El-Sisi's authorities in excluding the Moslem Brotherhood from Egypt's political arena was feared to be the same experience as Algeria back in 1992, when the military there boycotted the electoral victory of the Islamist party, the Islamic Salvation Front (ISF), in Algeria in 1991. The Algerian military then suspended the constitution, forced the president from power and took over the transitional government. The Algerian Islamic groups that had been repressed and persecuted turned to the extremist groups and performed terrors that led to a prolonged Algerian conflict (Zaretsky 2013).

The Algerian bad experience was feared to be reoccurring in Egypt when Sisi's authority excluded the Moslem Brotherhood in Egypt's domestic political sphere. The deepening polarization of and discrimination towards marginalized Islamist groups, has resulted in a prolonged conflict that is hindering the future prospects of Egypt's democratization.

\section{Why has the recent transition failed?}

In his short speech before members of Egypt's newest parliament in the first quarter of 2016, President Abdul Fatah El-Sisi revealed that Egypt has successfully passed the transition phase and has established a democracy. The president also claimed that the country has rebuilt the foundations of democratic elements such as institutional and constitutional law (The New Arab 2016). Egypt itself has been without a parliament since its dissolution in 2012.

Has the Egyptian transition to democracy been successfully achieved, despite the government's massive repression?

Previously, in the period of the post-Morsi era, when Egypt was managed by the military-backed interim government in the absence of parliament, 
and in the face of civil unrest, Mansour issued a number of laws that have curtailed the liberty of civilians. The protest law, released in November 2013, regulates a set of regulations for forming an association and a set of regulations to be followed when holding protests and demonstrations. It also stipulates the number of people and places allowed to hold such events (Brown 2014).

In addition to the protest law, there are university regulations issued by the Supreme Council of the Universities, one of the bodies under the Ministry of Higher Education of Egypt, allowing interdiction and prohibition of demonstrations and associations related to political parties (Brown 2014).

If we look at the prospect of stability and democratization in Egypt, Egypt still has a long way to achieve real democracy. In the era of Sisi, the number of detained, tortured, and arrested journalists has significantly increased. The suppression of opposition groups has been carried out by the issuance of various laws restricting the people's freedom of expression. The oppression to the Moslem Brotherhood and the labelling of the FJP as a terrorist group were forms of suppression of Islamist groups in Egypt.

In the third quarter of 2015, Sisi approved additional drafting of antiterrorism laws, stipulating that terrorism is the act of violence, intimidation, and threats addressed to the government and civilians in public, that threatens the security of the country. In this case, the journalist and reporter who incite and spread false news regarding the government, the military forces, and the police are included as terrorists and are sanctioned in accordance to existing laws (Sirgany 2015)

Yet, in fact, the arrest and detainment of journalists by the military and police was commonly known in the post-Morsi era. As noticed by Alfred Stepan, democracy cannot be interpreted solely through electoral democracy, especially when the electoral system seems far from fair and free. In the post-Mubarak period, Egypt indeed had elements of substantive democracy, such as civil society, civil liberties, media, and NGOs. But while still in development, these nascent elements were challenged and restricted during Sisi's rule. This was worsened by the exclusion of the Moslem Brotherhood from Egypt's political landscape, indicating that the government marginalized one particular group that 
was perceived to have ruined the ongoing transition process.

The report shows that Egypt is not free, which is proven by a lack of freedom of speech as one of the fundamental rights of citizens. Moreover, most of the magazines and televisions belong to the government limiting the publication of independent media (Mohammadpour 2016: 147-153).

In the period after Morsi, the detainment of local and foreign journalists increased significantly, with 25 journalists in custody until December 2016. This makes Egypt the second largest country in the world regarding the number of journalist prisoners, preceded only by China with 38 journalist prisoners (Committee to Protect Journalists 2016).

The latest Global Terrorism Index report highlights that the country's global terrorism index has significantly increased. Egypt ranks 13th out of 162 countries on the global terrorism index. Acts of terrorism in Egypt increased in 2015 and 2016 when the country jumped to 9th rank with the death toll reaching 662 until 2016 (Terrorism Index 2016).

Consequently, security threats have harmed the country's stability. According to the latest report from Aljazeera, the escalation of terrorist attacks has significantly increased in Egypt since Morsi's overthrow in 2013. The violent attacks were mainly located in the Sinai Peninsula (A) Jazeera 2016).

From 2013 to 2016, 60,000 Egyptians and foreigners have been arrested by security forces (Reiter 2016). Local human rights organizations reported that there were 326 extrajudicial killings committed by security and intelligence agencies in 2015. The number increased to 754 cases by mid2016 (Hamzawy 2017: 20)

Up to June 2016, the Sisi administration had imposed 218 of a total of 554 travel bans in Egypt since 2011 . The report from the Association of Freedom of Thought and Expression (AFTE) states that the majority of individuals banned from entering the country were researchers and academics, whose research generally criticize Sisi's administration (Magid 2016).

Article 89 of the law regarding the establishment and role of NGOs, 
restricted the activities of NGOs and was passed by the Egyptian parliament in November 2016. Previously, in October 2016, the local courts approved the freeze of assets of 5 human rights activists and 3 NGOs accused of receiving financial aid from abroad, which were believed to be threatening security and national stability (Najjar 2017).

As Michael Schulz and Larry Diamond previously argued, civil society has an imperative role in transition processes, as they act as forerunners for the improvement of democratization in the Middle East. In Egypt, while Mubarak and his predecessor maintained the ruling bargain with the people, in return for restricting the role of civil society, Sisi's administration took the same path as his predecessor in diminishing its role. Yet, it is still not clear how Sisi could maintain the bargain with the people in the midst of upheaval and disunion after Morsi's ouster. This is why democratization in Tunisia is much better than in Egypt. As in Tunisia, post-Ben Ali's resignation, civil society played a massive role in keeping an eye on the government's activities.

In Egypt's 1971 constitution, the country was portrayed as democratic, in return for holding both legislative and presidential elections, along with periodic referenda since 1950. Yet, this was no more than a pseudodemocracy filled with government manipulation (Winter 2015: 9). It seems like this pseudo-democracy still runs in Egypt today. Claiming that the country had completed democratic transition, it was obvious that President Sisi wanted to get recognition from the world, despite the tumultuous events, restrictions, and regulations limiting Egyptians from speaking or acting freely during his regime.

It seems like the Pharaohs still cast a shadow over Egyptians every day, in order to maintain their power and interest. When the Islamist Morsi won the 2012 presidential election, they feared that Morsi would diminish their power and turn the country into an Islamic state. Therefore, they had to use any and all measures in order to maintain their interests and power. These measures were depicted previously, in the section explaining the coup against Morsi.

In this democratic era where non-democratic countries are marginalized and face many international pressures to turn to democracy, Sisi's 
authority insisted that Egypt has completely upheld both the procedural and electoral elements of democracy. But in reality, it is part of his tactic to upgrade autocracy in Egypt by diminishing the elements upgrading democracy, civil society, media freedoms, NGOs, and journalists.

It has been seven years since Mubarak's dismissal from power, and three years since the first democratically elected president's ouster by the military. At the beginning, Sisi's presidency established various policies in order to stabilize the country. In the midst of cleavages between the Islamists, secularists, and military forces, it seemed difficult for Sisi to maintain the ruling bargain that could gratify all these divided groups.

With the military forces persistently showing praetorian characteristics, it would be hard for a civilian president with no military background to endure a presidential term. If President Sisi persists in diminishing the role of civil society and NGOs, excluding the Moslem Brotherhood, arresting and detaining journalists and subjecting people to military trials, all the prospects of democratization in Egypt will only be an illusion.

\section{Conclusion}

The recent transition failed due to the shadow of Egypt's previous regime hindering the transitional and democratization process. The situation was worsened by military supremacy over the political sphere, most obviously seen through the military coup which toppled Mohammad Morsi from power. Morsi's ouster through the coup shows the flaws in the transitional process being formed since Mubarak's downfall.

Many believe that the recent situation in Egypt is worse than compared to the Mubarak era. The restriction of journalism and media, the military trials of civilians, tortures and detentions by the armed forces, and the control of civil society and NGOs prove that the current regime is not different from its predecessor prior to the Arab Spring in 2011. 
In sum, the success of Egypt's democratization in post-Arab Spring Egypt is an illusion as long as the country's current ruling elites, military forces, judiciary, and Mubarak remnants insist on maintaining their longstanding authoritarian tendencies in domestic affairs. The reluctance of these actors to move the country towards democratic consolidation has left all the Egyptians' efforts and struggles in establishing and preserving democracy in vain. 


\section{Bibiliography}

Achy, L., 2012. The Breakdown of the Arab Authoritarian Bargain. Carnegie Middle East Center, 9 January [online]. Available at: http:// carnegie-mec.org/2012/01/09/breakdown-of-arab-authoritarianbargain-pub-46414 (Accessed 31 August 2017).

Al Jazeera, 2016. Major Attacks in Egypt. Aljazeera, 13 July [online]. Available at: http://www.aljazeera.com/indepth/interactive/2015/01/majorattacks-egypt-150130161541922.html (Accessed 3 July 2017).

Al-Amin, E., 2013. The Grand Scam: Spinning Egypt's Military Coup. Counter Punch, 19 July [online]. Available at: http://www.counterpunch. org/2013/07/19/the-grand-scam-spinning-egypts-military-coup/ (Accessed 15 July 2016).

Aly, A. M. S. and Essaila, S., 2016. Egypt's 2015 Parliamentary Elections: A Prelude to Stability? Middle East Brief. 98

Arafat, A., 2011. Hosni Mubarak and the Future of Democracy in Egypt. Basingstoke: Palgrave Macmillan.

Baker, R. W., 1981. Sadat's Open Door: Opposition from Within. Social Problems, 28(4): 378-384.

Barnett, M. N. and Levy, J. S., 1991. Domestic sources of alliances and alignments: the case of Egypt, 1962-73. International Organizations, 45(3): 369-395.

Bassiouni, M., 2013. Confrontation: The Muslim Brotherhood's Last Big Stand and the Regime's Repressive Reactions -Where is Egypt Going? 17 August [online]. Available at: http://mcherifbassiouni.com/wpcontent/uploads/Egypt-Update-22.pdf (Accessed 15 July 2016).

Brown, B. and Bentivoglio, K., 2014. Egypt's Resurgent Authoritarianism: It's a Way of Life. Carnegie Endowment for International Peace, 9 October [online]. Available at: http://carnegieendowment. org/2014/10/09/egypt-s-resurgent-authoritarianism-it-s-way-of-life (Accessed 15 March 2016). 
Brownlee, J., 2007. Authoritarianism in an Age of Democratization. Cambridge: Cambridge University Press.

Committee to Protect Journalists, 2016. 2016 Prison Census: 259 Journalists Jailed Worldwide. [online]. Available at: https://cpj.org/ imprisoned/2016.php (Accessed 3 July 2017).

Diamond, L. J., 1999. Developing democracy: toward consolidation. Baltimore: Johns Hopkins University Press.

Dunne, M. and Hamzawy, A., 2008. The Ups and Downs of Political Reform in Egypt. In: Ottaway, M. and Chouchair-Vizoso, J. eds. Beyond the Façade: Political Reform in the Arab World. Washington D.C.: Carnegie Endowment for International Peace.

El-Adawy, A., 2013. Egypt's Interim Cabinet: Challenges and Expectations. 23 July [online]. Available at: http://www.washingtoninstitute. org/policy-analysis/view/egypts-interim-cabinet-challenges-andexpectations (Accessed 16 March 2016].

El-Dine, C. C., 2014. Fragile Alliances in Egypt's Post-Revolutionary Order: The Military and Its Partners. [pdf]. Available at: https://www.files. ethz.ch/isn/185251/2014C46_chams_el_dine.pdf (Accessed 15 March 2016).

El-Sherif, A., 2014. Egypt's Post-Mubarak Predicament. Carnegie Endowment for International Peace, 29 January [online]. Available at: http://carnegieendowment.org/2014/01/29/egypt-s-postmubarak-predicament-pub-54328 (Accessed 31 August 2017).

Farid, D., 2014. Egypt's economy over three years of turmoil. Daily News Egypt, 20 September [online]. Available at: http://www. dailynewsegypt.com/2014/09/20/egypts-economy-three-yearsturmoil/ (Accessed 10 July 2016).

Fisher, M., 2013. Here's the Egyptian military's full statement warning it may act in 48 hours. Washington Post, 1 July [online]. Available at: https:// www.washingtonpost.com/news/worldviews/wp/2013/07/01/ heres-the-egyptian-militarys-full-statement-warning-it-may-act-in48-hours/ (Accessed 15 March 2016).

Gerbaudo, P., 2013. The roots of the coup. Soundings, (54): 105-113. 
Ghannouchi, R., 2014. Tunisia shows there is no contradiction between democracy and Islam. [online]. Available at: https://www. washingtonpost.com/opinions/tunisia-shows-there-is-no-contradictionbetween-democracy-and-islam/2014/10/24/2655e552-5al6-1 1e4bd61-346aee66ba29_story.html (Accessed 7 July 2017).

Hamzawy, A., 2017. Legislating authoritarianism: Egypt's new era of repression. Carnegie Endowment for International Peace, [pdf]. Available at: http://carnegieendowment.org/files/CP_302_ Hamzawy_Authoritarianism_Final_Web.pdf

Hassan, H. A., 2010. State versus society in Egypt: Consolidating democracy or upgrading autocracy. African Journal of Political Science and International Relations, 4(9): 319-329.

Hawthorne, A., 2004. Middle Eastern Democracy: Is Civil Society the Answer? Carnegie Endowment for International Peace, 1 March [online]. Available at: http://carnegieendowment.org/2004/03/01/ middle-eastern-democracy-is-civil-society-answer-pub- 1463 (Accessed 2 July 2017).

Haynes, J., 2013. An introduction to international relations and religion. Abingdon: Routledge.

Huntington, S. P., 1991. Democracy's Third Wave. Journal of Democracy, $2(2): 12-34$.

Huntington, S. P., 2006. Political Order in Changing Societies. New Haven: Yale University.

Kamrava, M., 2014. Beyond the Arab Spring: The Evolving Ruling Bargain in the Middle East. Oxford: Oxford University Press.

King, S. J., 2009. The New Authoritarianism in the Middle East and North Africa. Bloomington: Indiana University Press.

Kuncahyono, T., 2013. Tahrir Square: jantung revolusi Mesir. Penerbit Buku Kompas, Jakarta.

Lando, B., 2013. Egypt's Military State Within a State. [online] Available at: http://www.huffingtonpost.com/barry-lando/egypt-coup_b_3545469. html (Accessed 3 July 2017). 
Lombardi, C. B. and Brown, N. J., 2006. Do Constitutions Requiring Adherence to Shari'a Threaten Human Rights? How Egypt's Constitutional Court Reconciles Islamic Law with the Liberal Rule of Law. American University International Review, 21 (3): 379-435.

Magid, P., 2016. Understanding 554 travel bans since 2011 . Mada, [online]. Available at: https://www.madamasr.com/en/2016/06/28/feature/ politics/understanding-554-travel-bans-since-2011/ (Accessed 23 June 2017).

Mannheimer, E., 2014. Why Egypt, but not Tunisia?. [online] Available at: https://lup.lub.lu.se/student-papers/search/publication/4448122 (Accessed 15 March 2016).

Malik, A. and McCormick, T., 2011. Egypt: The More Things Change. [online] Available at: http://www.aljazeera.com/indepth/ opinion/2011/11/20111122131237831652.html (Accessed 1 September 2017).

Mohammadpour, I., 2016. Analysis of the Role of the Press in the Egyptian Revolution of 2011. Journal of Politics and Law, 9(10): 145-155.

Najjar, F., 2017. Egypt's NGO law aims to "erase civil society". [online]. Available at:http://www.aljazeera.com/indepth/features/2017/02/ egypt-ngo-law-aims-erase-civil-society-170215121321442.html (Accessed 5 July 2017).

Nanz, P., and Steffek, J., 2004. Global governance, participation and the public sphere. Government and Opposition, 39(2): 314-335.

Nassif, H. B., 2013. Wedded to Mubarak: The Second Careers and Financial Rewards of Egypt's Military Elite, 1981-2011. Middle East Journal, 67(4): 509-530.

O'Donell, G. A., 1994. Delegative Democracy. Journal of Democracy, 5(1): 55-69.

O'Donnel, G., Schmitter, P., and Whitehead, L. eds., 1986. Transitions from authoritarian rule. Vol I-IV Baltim.

O'Donnell, G., Cardoso, F. H., Woodrow Wilson International Center for Scholars, eds., 1991. Transitions from Authoritarian Rule: Comparative Perspectives. Baltimore: The Johns Hopkins University Press. 
Pappalarado, J., 2011. Analysis: Dissecting America and Egypt's Military Relationship. [online]. Available at: http://www.popularmechanics. com/technology/military/news/dissecting-america-and-egyptsmilitary-relationship-5168761 (Accessed 16 March 2016).

Perlmutter, A., 1977. The Military and Politics in Modern Times: On Professionals, Praetorians, and Revolutionary Soldiers. New Haven: Yale University Press.

Perlmutter, A., 1974. Egypt: The Praetorian State. New Brunswick: Transaction Books.

Radsch, C. C., 2013. Media Wars in Egypt: The Revolution Continues with Journalists in the Crosshairs. Huffington Post, [online]. Available at: http://www.huffingtonpost.com/courtney-c-radsch/media-warsin-egypt-the-r_b_3548032.html (Accessed 15 March 2016).

Reiter, M., 2016. Egypt's Guantanamo: Scorpion Prison. Human Rights Brief, 8 November [online]. Available at: http://hrbrief.org/2016/1 1/ egypts-guantanamo-scorpion-prison/

Reporters without Borders: for Freedom of Information, 2017. Data of Press Freedom Ranking. [online]. Available at: https://rsf.org/en/ranking_ table (Accessed 28 September 2017).

Sayigh, Y., 2012. Above the State: The Officers' Republic in Egypt. Carnegie Middle East Center, [online]. Available at: http://carnegie-mec. org/publications/?fa=48972 (Accessed 15 March 2016).

Schulz, M., 2011. The Role Of Civil Society In Regional Governance In The Middle East. Civil Society and International Governance, 166.

Selim, G. M., 2015. The International Dimensions of Democratization in Egypt: The Limits of Externally-Induced Change. New York: Springer.

Sirgany, S., 2015. New terrorism law could target journalists in Egypt. CNN, 6 July [online]. Available at: http://www.cnn.com/2015/07/05/ africa/egypt-terrorism-law-journalists/index.html (Accessed 15 March 2016).

Sørensen, G., 2008. Democracy and Democratization: Processes and Prospects in a Changing World. 3rd ed. Boulder: Westview Press. 
Stein, E., 2012. After the Arab Spring: power shift in the Middle East: revolutionary Egypt: Promises and perils. LSE Library Services, [online]. Available at: http://eprints.Ise.ac.uk/43461/ (Accessed 1 October 2017).

Stepan, A. C., 2000. Religion, Democracy, and the "Twin Tolerations". Journal of Democracy, 11 (4): 37-57.

Terrorism Index, 2016. Global Terrorism Index. Institute for Economics and Peace, [pdf]. Available at: http://economicsandpeace.org/ wp-content/uploads/2016/11/Global-Terrorism-Index-2016.2.pdf (Accessed 1 October 2017).

The New Arab, A., 2016. President Sisi says democracy is returning to Egypt. Alaraby, 13 February [online]. Available at: https://www.alaraby. co.uk/english/news/2016/2/13/president-sisi-says-democracy-isreturning-to-egypt (Accessed 15 March 2016).

Winter, O., 2015. El-Sisi's First Year as President: Legitimacy, Democracy, and Relations with Israel. Strategic Assessment, 18(2): 9-20.

Cammack, P., Dunne, M., Hamzawy, A., Lynch, M., Muasher, M., Sayigh, Y. and Yahya, M., 2017. Arab Fractures: Citizens, States, and Social Contracts. Carnegie Endowment for International Peace, [online]. Available at: http://carnegieendowment.org/2017/02/01/ arab-fractures-citizens-states-and-social-contracts-pub-66612 (Accessed 2 July 2017).

Zaretsky, R., 2013. Egypt's Algerian Moment. Foreign Policy, 20 August [online]. Available at: https://foreignpolicy.com/2013/08/20/ egypts-algerian-moment/ (Accessed 15 March 2016).

Gonda Yumitro (gonda@umm.ac.id) is Assistant Professor as well as the Head of Department of International Relations, University of Muhammadiyah Malang. He studied at Gadjah Mada University, Indonesia, Jamia Millia Islami and Annamalai 
ص University, India. His research focuses on various issues of Islamic global affairs and political Islam. Moreover, he has been publishing in a national monthly magazine in Indonesia for the past five years.

Heavy Nala Estriani (heavynala.hn@gmail.com) is currently an MA student at the International Relations Department of Airlangga University. She is particularly focused on International peace and security studies. She defended her BA on the topic of the role of the military in Egyptian politics in the post-Hosni Mubarak period at the University of Muhammadiyah Malang. Her interests include international security, Middle Eastern area studies and civil-military relations. 